\title{
The Impact of Monetary Policy on Lending and Deposit Rates in Pakistan: Panel Data Analysis
}

\section{Hasan Muhammad Mohsin*}

\begin{abstract}
This study estimates the impact of monetary policy on lending and deposit rates in Pakistan, using bank data for the period November 2001 to March 2011. We find evidence of a long-run relationship between the lending and discount rate, but the deposit rate is not co-integrated, and the pass-through is not complete. The study finds that, overall, banks pass on only 20 percent of the impact of a change in the discount rate to lenders in the first month. There is also a significant difference among various banks' pass-through rates. A shortrun analysis reveals that the pass-through of the deposit rate is low at 0.16, which implies that the effectiveness of monetary policy is limited in Pakistan.
\end{abstract}

Keywords: Monetary Policy, Lending, Deposit Rates, Pakistan.

JEL Classification: E43, E52.

\section{Introduction}

The interest rate is one of the tools of monetary policy. Passthrough refers to the transmission of the benchmark interest rate-the discount rate in this case-to the lending and deposit rates in the economy. The pass-through is completed when any change in the discount rate is immediately transmitted to the lending and deposit rates (Bernanke \& Blinder, 1992; C. Romer \& Romer, 1989). The completeness implies that monetary policy is very effective and that the central bank can influence output and consumption without much delay.

Many studies have estimated the degree of pass-through for developed countries, e.g., in Europe, the US, and the UK (see de Bondt, 2002; De Graeve, De Jonghe, \& Vander Vennet, 2004; Kleimeier \& Sander, 2006; Liu, Margaritis, \& Tourani-Rad, 2008; Mojon, 2000; Sørensen \& Werner, 2006). However, there is no consensus on the completeness of pass-through. Some studies report completeness in the pass-through

${ }^{*}$ Research Economist, Pakistan Institute of Development Economics (P.I.D.E), Islamabad. 
process with respect to benchmark monetary policy instruments (see Altunbas, Fazylov, \& Molyneux, 2002; Bernanke \& Gertler, 1995; Cook, 2008; Kashyap \& Stein, 2000). Others contradict these findings and provide empirical evidence in favor of the incompleteness of pass-through. They also find heterogeneity across countries, financial institutions, and retail bank products (see de Bondt, 2002; Hofmann \& Mizen, 2004; Liu et al., 2008; Mojon, 2000; Ozdemir, 2009). The studies that focus on pass-through in the Euro zone use nonharmonized retail interest rate statistics (see de Bondt, 2002, 2005; Heinemann \& Schüller, 2002; Mojon, 2000; Sander \& Kleimeier, 2002, 2004; Toolsema, Sturm, \& de Haan, 2002). Some studies use individual retail bank data (see Cottarelli, Ferri, \& Generale, 1995; De Graeve et al., 2004; Gambacorta, 2004; Weth, 2002).

Ozdemir (2009) estimates pass-through between the money market rate and bank retail rate for Turkey. There is a limited body of literature on developing countries such as Pakistan. Qayyum, Khan, and Khawaja (2005) estimate the pass-through of the treasury bill rate on the call money rate, savings deposit rate, six-month deposit rate, and lending rate. They use data for the six-month deposit rate and lending rate for the period March 1991 to December 2004, while employing the transfer function approach. Mohsin and Rivers (in press) measure the pass-through between the treasury bill rate and retail rate for Pakistan, and find that the degree of pass-through is moderately high although the pass-through is not complete. The State Bank of Pakistan presently uses the discount rate as a monetary policy tool, although it has used various other tools as well.

This study attempts to measure the pass-through between the discount rate and retail rate, using monthly data for the period November 2001 to March 2011. We use data for the weighted average lending and deposit rates for four types of banks, i.e., private domestic, foreign, nationalized, and specialized. A comparison of the pass-through in the case of various categories of banks' retail rates and discount rates will be an interesting extension of ongoing research in Pakistan.

\section{Methodology}

We use a panel data technique by applying panel unit root tests to check for the stationarity of data, followed by the Pedroni panel cointegration test to check for a long-run relationship between the discount rate and lending and deposit rates. We also apply the Phillips and Loretan (1991) method, which is an extension of Engle and Granger (1988), using cross-section dummies. 


\subsection{Panel Unit Root Test}

We utilize three panel unit root tests to assess the stationary of the data on the discount rate and lending and deposit rates (Hadri, 2000; Im, Pesaran, \& Shin, 2003; Levin, Lin, \& Chu, 2002).

The Levin-Lin-Chu (LLC) test assumes that persistence parameters remain the same across cross-sections. This means that $i=$ for all $i$. Alternatively, the Im-Pesaran-Shin test allows to vary across all cross-sections.

The LLC model allows for fixed effects and a unit-specific time trend along with common time effects. The structure of the model is shown below:

$$
\Delta y_{i t}=\alpha_{i}+\delta_{i} t+\theta_{t}+\rho_{i} y_{i, t-1}+\xi_{i t}, i=1,2 \ldots N, t=1,2 \ldots T
$$

The unit-specific fixed effect is important in order to capture heterogeneity since the coefficient of the lagged dependant variable is homogeneous across all cross-sections in Equation 1. Im et al. (2003) extended the LLC framework by allowing heterogeneity in $i$ under the alternative hypothesis. Hadri's (2000) Lagrange multiplier test has a different null hypothesis from other panel unit root tests. A comparison of the results from all three tests will be interesting and provide stronger evidence (see Banerjee, 1999; Mohsin \& Rivers, in press).

\subsection{Panel Co-Integration}

We use the Pedroni $(1999,2004)$ panel co-integration test to estimate a long-run relationship between bank and treasury bill rates. Pedroni derived seven tests that are within and between dimensions, and are residual-based, similar to the Engle-Granger test. The slope coefficients vary over cross-section units, thereby allowing heterogeneity within the model. The panel equation is estimated as

$$
Y_{i t}=\alpha_{i}+\delta_{i t}+\beta_{i} X_{i t}+\varepsilon_{i t}
$$

Here, $i=1,2 \ldots \ldots \ldots . N$ cross-sectional units, $t=1,2 \ldots \ldots \ldots . . T$ time periods, and $X_{i t}$ represents the column vector, which consists of $M$ independent variables for each $i$ th unit. $M$ represents the number of independent variables. The variables $Y$ and $X$ are considered to be nonstationary, I (1). 
integrated of order one. The parameters The residual will be nonstationary, $I(1)$, under the hypothesis of no co-integration.

The parameters $\alpha_{i}$ and $\delta_{i t}$ capture cross-sectional fixed effects and deterministic trends, respectively. The different slope coefficients $\beta_{\mathrm{i}}$ allow for the possibility that co-integrating vectors are also heterogeneous.

To compute the required panel-co-integrating statistic, we estimate Equation 1 using ordinary least squares (OLS) for every individual cross-section. The within-dimension-based estimates are panel and panel $t$ statistics, and are derived by computing the first difference of all variables.

$$
\Delta Y_{i t}=\beta_{1 t} \Delta X_{1 i t}+\beta_{2 t} \Delta X_{2 i t}+\cdots \ldots \ldots \beta_{m t} \Delta X_{m i t}+\pi_{i t}
$$

\subsection{Phillips and Loretan (PL) (1991) Method}

The marginal cost-pricing model uses an Engle-Granger-type equation (see de Bondt, 2002, 2005; Rousseas, 1985).

$$
\begin{aligned}
& Y_{i t}=\alpha_{i}+\beta X_{i t}+\varepsilon_{i t} \\
& \mathrm{i}=1,2, \ldots \ldots, \mathrm{N} \text { and } \mathrm{t}=1,2 \ldots \ldots \ldots \mathrm{T}
\end{aligned}
$$

Where $Y_{i t}$ represents bank lending or deposit rate, $X_{i t}$, the monetary policy instrument, discount rate, money market rate, or federal fund rate; and, the residual term, while $\alpha_{i}$ and measure the markup and long-run degree of pass-through, respectively.

Liu et al. (2008) estimate the following triangular system of equations to model the long-run relationship between the policy rate and market rate:

$$
\begin{aligned}
& Y_{i t}=\alpha_{i}+\beta X_{i t}+U_{i t}, \quad \mathrm{t}=1,2, \ldots \ldots, \mathrm{T} \\
& X_{i t}=X_{i t-1}+U_{2 i t}
\end{aligned}
$$

Where $U_{i t}=\left[U_{1 i t}, U_{2 i t}\right]^{\prime}$ is a stationary vector.

Estimating Equation 1 requires both interest rates to be nonstationary. If $U_{1 i t}$ is not stationary, then $U_{2 i t}$ interest rates will not cointegrate, thereby resulting in a spurious estimate. 
Liu et al. (2008) reveal that, even if $U_{1 i t}$ is stationary, OLS estimates of Equations 1 and 1a do not have a standard distribution when $U_{1 i t}$ and $U_{2 i t}$ are correlated. Phillips and Loretan (1991) suggest including leads and lags of the first difference in $X_{t}, \Delta X_{t}$. They estimate the following equation:

$$
Y_{i t}=\alpha_{i}+\beta_{i} X_{i t}+\sum_{k=1}^{K} d 1 k\left(Y_{i t-k}-\alpha_{0}-\beta_{i} X_{i t-k}\right)+\sum_{i=-1}^{L} d 2 \Delta X_{i t-1}+V_{i 1 t}
$$

The parameter estimates are unbiased asymptotically and normally distributed. Using this model has two additional advantages. First, it considers structural changes, should they occur; and second, it addresses past policy surprises and future policy settings with regard to policy instruments and bank rates.

\section{Results}

\subsection{Long-Run Results}

Table 1 provides a summary of the panel unit root tests (individual as well as common process) that have been applied to check for the stationarity of three variables, i.e., weighted average lending, deposit rate, and discount rate (monetary policy instrument). In most cases, we fail to reject the null hypothesis of a unit root at levels since the computed probabilities are greater than 0.05. However, we also reject the hypothesis of unit root at first difference in most cases, which implies that the variables are nonstationary at levels but stationary at first difference, hence integrated of order one. In the case of the Hadri test, we reject the null hypothesis of stationarity for all three variables but fail to reject the null hypothesis at first difference. Now, in order to find evidence of a long-run relationship, we apply a panel co-integration analysis.

Table 1: Panel Unit Root Tests

\begin{tabular}{|c|c|c|c|c|c|c|c|c|}
\hline \multirow[t]{2}{*}{ Method } & & \multirow[t]{2}{*}{ Null Hypothesis } & \multicolumn{2}{|c|}{ Lending } & \multicolumn{2}{|c|}{$\begin{array}{l}\text { Deposit } \\
\text { Rate }\end{array}$} & \multicolumn{2}{|c|}{$\begin{array}{l}\text { Discount } \\
\text { Rate }\end{array}$} \\
\hline & & & Stat. & Prob. & Stat. & Prob. & Stat. & Prob. \\
\hline \multirow[t]{2}{*}{$\begin{array}{l}\text { LLC-t* } \\
\text { stat. }\end{array}$} & Level & $\begin{array}{l}\text { Unit root (common } \\
\text { process) }\end{array}$ & -1.19 & 0.42 & -3.03 & 0.99 & -2.70 & 0.99 \\
\hline & 1st diff. & & -15.84 & 0.00 & -8.05 & 0.00 & -6.87 & 0.00 \\
\hline \multirow[t]{2}{*}{ Hadri-Z } & Level & Stationary & -6.70 & 0.00 & 9.50 & 0.00 & 8.67 & 0.00 \\
\hline & 1st diff. & & 2.64 & 0.06 & -0.87 & 0.20 & -0.73 & $0.77^{*}$ \\
\hline \multirow[t]{2}{*}{$\begin{array}{l}\text { IPS-W } \\
\text { stat. }\end{array}$} & Level & $\begin{array}{l}\text { Unit root } \\
\text { (individual process) }\end{array}$ & -1.28 & 0.10 & 3.20 & 0.99 & -1.09 & 0.13 \\
\hline & 1st diff. & & -16.57 & 0.00 & -7.80 & 0.00 & -10.24 & 0.00 \\
\hline
\end{tabular}

IPS = Im-Pesaran-Shin, LLC = Levin-Lin-Chu. 
* : are significant at 1 percent respectively.

Source: Author's calculations.

Table 2 summarizes the residual-based Pedroni's panel cointegration test applied to the lending rate and discount rate. In the within-dimension test, seven out of eight tests reject the null hypothesis of no co-integration. Similarly, in the between-dimension case, the null hypothesis of no co-integration can be rejected in two out of three cases. The group ADF stat has a probability of 0.06 , which is higher than 0.05 . Overall, the Pedroni co-integration test yields ample evidence of a longrun relationship between the lending rate and discount rate.

Table 2: Pedroni Residual-Based Panel Co-Integration Test Variables: Lending Rate and Discount Rate

\begin{tabular}{lclcl}
\hline Ho: No Co-Integration & & & & \\
Ha: Within Dimension & Statistic & Prob. & Weighted Stat. & Prob. \\
\hline Panel V stat. & 1.90 & $0.030^{* *}$ & 1.20 & $0.10^{* * *}$ \\
Panel rho-stat. & -1.80 & $0.040^{* *}$ & -1.33 & $0.09^{* * *}$ \\
Panel PP-stat. & -1.90 & $0.020^{* *}$ & -1.70 & $0.04^{* *}$ \\
Panel ADF-stat. & -1.60 & $0.005^{* *}$ & -1.50 & $0.00^{*}$ \\
\hline Ha: Between Dimensions & & & & \\
Group rho-stat. & -2.21 & $0.010^{*}$ & & \\
Group PP-stat. & -2.22 & $0.010^{*}$ & & \\
Group ADF-stat. & -1.50 & $0.060^{* * *}$ & & \\
\hline
\end{tabular}

Note: ${ }^{* * *}$, and ${ }^{* * *}$ are significant at 1,5 , and 10 percent, respectively.

Source: Author's calculations.

Next, we examine the long-run relationship between the deposit rate and discount rate. Table 3 summarizes the Pedroni residual-based panel co-integration tests applied to the deposit rate and discount rate. In eight within-dimension tests, the computed probabilities are estimated to be very high. We fail to reject the null hypothesis of no co-integration in all eight cases. Hence, there is a strong probability of a long-run relationship between the deposit rate and discount rate in the withindimension tests. Similarly, in the three between-dimension tests, the computed probabilities are more than 0.90, which is much higher than 0.05 . Here, too, we fail to reject the null hypothesis of no co-integration. Sørensen and Werner (2006) find similar results for savings deposits in the Euro area, using the Pedroni residual-based test. They argue that there is no co-integration with the market rate possibly because the adjustment in savings deposits is so sluggish. 
Table 3: Pedroni Residual-Based Panel Co-Integration Test Variables: Deposit Rate and Discount Rate

\begin{tabular}{lcccc}
\hline $\begin{array}{l}\text { Ho: No Co-Integration } \\
\text { Ha: Within Dimension }\end{array}$ & Statistic & Prob. & Weighted Stat. & Prob. \\
\hline Panel V stat. & 0.28 & 0.40 & 0.55 & 0.30 \\
Panel rho-stat. & 1.70 & 0.95 & 1.40 & 0.91 \\
Panel PP-stat. & 2.71 & 0.99 & 2.24 & 0.98 \\
Panel ADF-stat. & 2.61 & 0.99 & 2.13 & 0.98 \\
\hline Ha: Between Dimensions & & & & \\
Group rho-stat. & 1.30 & 0.89 & & \\
Group PP-stat. & 2.44 & 0.99 & & \\
Group ADF-stat. & 2.34 & 0.99 & & \\
\hline
\end{tabular}

Note: None of the computed probabilities less than 0.10 are not significant.

Source: Author's calculations.

\subsection{PL Estimates with Slopes and Intercept Dummies}

Table 4 reports three types of estimated equations for both lending and deposit rates. 
Table 4: PL Estimates with Dummy Variables

\begin{tabular}{llll}
\hline & \multicolumn{2}{c}{ Lending-Deposit Rates } & \\
& Eq. 1 & Eq. 2 & Eq. 3 \\
\hline Cons. & 7.80 & 7.82 & 8.10 \\
& $(9.50)^{*}$ & $(9.80)^{*}$ & $(17.30)^{*}$ \\
DR (PL) & 0.20 & 0.10 & 0.15 \\
& $(2.70)^{* *}$ & $(1.80)^{* * *}$ & $(3.20)^{*}$ \\
DR-FB & & 0.15 & 0.15 \\
& & $(39.70)^{*}$ & $(43.90)^{*}$ \\
DR-NB & & 0.09 & 0.24 \\
& & $(16.20)^{*}$ & $(104.30)^{*}$ \\
DR-PB & & 0.22 & 0.32 \\
& & $(37.50)^{*}$ & $(138.20)^{*}$ \\
DR-SB & & & \\
DDR & & 0.25 & 0.20 \\
& 0.25 & {$[5.60]^{*}$} & $(3.05)^{*}$ \\
DERL & $(5.70)^{*}$ & 0.50 & 0.50 \\
C1-FB & 0.50 & $(45.30)^{*}$ & $(262.50)^{*}$ \\
& $(44.60)^{*}$ & & -2.40 \\
C2-PB & & & $(-23.80)^{*}$ \\
& & & -3.37 \\
C3-NB & & & $(-79.10)^{*}$ \\
C4-SDB & & & -1.80 \\
Chi-sq. & & $(-24.70)^{*}$ \\
R-sq. & & & \\
DW & & & \\
\hline
\end{tabular}

Notes: $1:$ Chi $=$ sq. pertains to the Wald coefficient restriction test.

DR-FB = slope dummy for foreign banks, DR-NB = slope dummy for domestic nationalized banks, DR-PB = slope dummy for domestic privatized banks, DR-SB = slope dummy for domestic specialized banks. C1-C4 = intercept dummies for 4 cross-section banks. DERL and DERD are the first difference of residual from EG-OLS equation for lending and deposit rates. DERL and DERD are the first difference of residual from EGOLS equation for lending and deposit rates.

Eq. 1 and 2 estimates with $\operatorname{AR}(1,2)$, Eq. 3 AR(1) only.

Source: Author's calculations.

Equation 1 estimates the PL model without bank-type dummies in an autoregressive of order 2 model to tackle autocorrelation. Equation 2 includes overall slope and bank-type dummies. The Wald test is applied to check whether bank types' pass-through is different from the overall estimated slope. Equation 3 gives slope as well as intercept dummies, in 
an autoregressive of order 1 equation. Equation 1 for the lending rate estimates the overall slope to be 0.20 , which is far below 1 , implying that the pass-through of the discount rate with a weighted average lending rate is not complete.

We note that the overall pass-through parameter decreases with the inclusion of autoregressive terms, but the Durbin-Watson (DW) improves. This means that banks pass on only 20 percent of the impact of a change in the discount rate to lenders immediately, which is very low. The overall pass-through in Equation 2 is estimated at 0.10 , implying that banks pass on only 10 percent of the impact of the discount rate to lenders in the first month overall. The estimated slope dummies show that the pass-through is lowest for specialized banks and highest for domestic private banks followed by foreign banks.

The estimated pass-through for private banks is 0.32 , followed by foreign banks at 0.25 . The estimated pass-through for nationalized banks is 0.19 . We apply the Wald test with a coefficient restriction, all slopes being equal. The estimated chi-square value is 7146431 and the probability is 0 . The null hypothesis of equality of slopes can be rejected in favor of at least one slope coefficient being different. This implies that there is heterogeneity in the response of the weighted average lending rate change when the discount rate is changed to implement monetary policy. The DW is 1.80 and goodness of fit explains 97 percent of the variation in the model.

Equation 3 for the lending rate estimates the overall pass-through along with slope and intercept dummies. The overall pass-through is 0.15 but the estimated slope parameter for private banks is 0.32 , followed by 0.24 for nationalized banks and 0.15 for foreign banks. In this AR (1) model, the DW statistic is 1.3. After the inclusion of AR (2), the results are similar to Equation 2. The study therefore considers Equation 2 to be the final result. The estimated pass-through is low, which implies that Pakistani banks only pass on a marginal impact of a change in the discount rate to lenders. It also implies that the effectiveness of monetary policy is limited in the first month and that the complete impact takes time.

\section{Short-Run Analysis of Deposit and Discount Rates}

Since the deposit rate and discount rate do not have a long-run relationship, the study extends the analysis to the short run. Table 5 reports the results in the form of three equations. The variables are in first 
difference form. Equation 1 estimates a fixed effects model in which the overall pass-through of the discount and deposit rates is estimated in the short run. The pass-through is 0.16 and is found to be statistically significant. This implies that, overall, banks pass on 16 percent of the impact of a change in discount rate in the first month to depositors.

Table 5: Short-Run Analysis of Deposit and Discount Rates

EQ. 1

$\mathrm{D}(\mathrm{DEP})=-0.002+0.16^{*} \mathrm{D}(\mathrm{DR})$

$(-0.13)(3.5)^{*}$

$\mathrm{R}^{2}=0.05 \quad$ F-Stat $=3.8$ Prob. $($ F-Stat $)=0.002$ DW $=1.93$

EQ. 2

$\mathrm{D}(\mathrm{DEP})=-0.02^{*} \mathrm{D}(\mathrm{DR})+0.20^{*} \mathrm{D}(\mathrm{DNB})+0.16^{*} \mathrm{D}(\mathrm{DPB})+0.3^{*} \mathrm{D}(\mathrm{DFB})$

$$
(-0.4)^{*} \quad(1.92)^{* *} \quad(1.40) \quad(1.96)^{* *}
$$

$\mathrm{R}^{2}=0.05 \quad$ F-Stat $=2.5$ Prob. $($ F-Stat $)=0.02 \quad \mathrm{DW}=2.3$

EQ. 3

$\mathrm{D}(\mathrm{DEP})=-0.003^{*} \mathrm{D}(\mathrm{DR})+0.20^{*} \mathrm{D}(\mathrm{DNB})+0.2^{*} \mathrm{D}(\mathrm{DPB})+0.3^{*} \mathrm{D}(\mathrm{DFB})+$ $(-0.04) \quad(1.9)^{* * *} \quad(1.3) \quad(2.01)^{* *}$

$\operatorname{AR}(1)=-0.14]$

$(-2.04)^{*}$

$\mathrm{R}^{2}=0.07 \quad$ F-Stat $=2.98$ Prob. (F-Stat) $=0.003 \quad \mathrm{DW}=1.94$

Source: Author's calculations.

Equation 2 adds bank-type-wise slope dummies. The overall slope is 0 but the pass-through for nationalized and foreign banks is found to be 0.2 and 0.3 , respectively. The parameter pertaining to privatized banks is 0.16 but is not statistically significant. Furthermore, the goodness-of-fit measure is only 0.05 .

Equation 3 estimates the same model with AR (1) since the DW statistic is 2.3 in Equation 2. The overall parameter is not statistically significant from 0 , whereas the slope parameters pertaining to nationalized and foreign banks are 0.2 and 0.3 , respectively. The goodness-of-fit measure improves slightly to 0.07 and the DW statistic is estimated at 1.94. The study finds an overall pass-through of 0.16 in the short run between the deposit and discount rates. There is evidence of 
asymmetry since the pass-through for various bank types is different. Overall, a higher pass-through of 0.3 is estimated for foreign banks and 0.2 for nationalized banks. The pass-through for privatized banks is estimated at 0.20 but is not significant.

\section{Conclusion}

This study has estimated the impact of the monetary policy instrument, the discount rate, on weighted average lending and deposit rates in Pakistan. We have used bank-type monthly data for the period November 2001 to March 2011. The four bank types are nationalized, privatized, foreign, and specialized. Panel data techniques have been used to estimate results.

The study has found that all three variables are nonstationary at levels and stationary at first differences. The Pedroni panel co-integration technique was applied to estimate a long-run relationship that reveals that the lending rate is co-integrated while deposit rate is not cointegrated with the monetary policy instrument. Since the lending and discount rates are co-integrated, The PL method was applied using banktype dummies. The results showed that the overall lending rate's passthrough is 0.20 , which is very low. However, there is evidence of asymmetry among various bank types since the pass-through for private, foreign, and nationalized banks is $0.32,0.25$, and 0.19 , respectively.

A short-run analysis in the case of the deposit and discount rates has shown that, overall, banks pass on 16 percent of the impact of the discount rate to depositors. The pass-through for foreign and nationalized banks is 0.30 and 0.20 , respectively. The estimates suggest that the overall effectiveness of monetary policy is limited and that there is a significant lag in its completeness. 


\section{References}

Altunbas, Y., Fazylov, O., \& Molyneux, P. (2002). Evidence on the bank lending channel in Europe. Journal of Banking and Finance, 26(11), 2093-2110.

Baltagi, B. H. (2000). Nonstationary panels, panel co-integration and dynamic panels: 15 (Advances in econometrics). JAI Press.

Banerjee, A. (1999). Panel data unit roots and cointegration: An overview. Oxford Bulletin of Economics and Statistics, 61, 607-629.

Bernanke, B., \& Blinder, A. (1992). Credit, money, and aggregate demand. American Economic Review, 82, 901-921.

Bernanke, B., \& Gertler, M. (1995). Inside the black box: The credit channel of monetary policy transmission. Journal of Economic Perspectives, 9(4), 27-48.

Bondt, G. de (2002). Retail bank interest rate pass-through: New evidence at the Euro-area level (Working Paper No. 136). Frankfurt, Germany: European Central Bank.

Bondt, G. de (2005). Interest rate pass-through: Empirical results for the Euro area. German Economic Review, 6(1), 37-78.

Cook, S. (2008). Econometric analysis of interest rate pass-through. Applied Financial Economics Letters, 4, 249-251.

Cottarelli, C., Ferri, G., \& Generale, A. (1995). Bank lending rates and financial structure in Italy: A case study (Working Paper No. 95/38). Washington, DC: International Monetary Fund.

Cottarelli, C., \& Kourelis, A. (1994). Financial structure, bank lending rates, and the transmission mechanism of monetary policy. International Monetary Fund Staff Papers, 41(4), 587-623.

De Graeve, F., De Jonghe, O., \& Vander Vennet, R. (2004). The determinants of pass-through of market conditions to bank retail interest rates in Belgium (Working Paper No. 47). Brussels: National Bank of Belgium. 
Donnay, M., \& Degryse, H. (2001). Bank lending rate pass-through and differences in the transmission of a single EMU monetary policy (Discussion Paper No. 0117). Leuven, Belgium: Katholieke Universiteit, Center for Economic Studies.

Gambacorta, L. (2004). How do banks set interest rates? (Working Paper No. 10295). Cambridge, MA: National Bureau of Economic Research.

Gropp, R., Sørensen, C. K., \& Lichtenberger, J.-D. (2007). The dynamics of bank spreads and financial structure (Working Paper No. 714). Frankfurt. Germany: European Central Bank.

Hadri, K. (2000). Testing for stationarity in heterogeneous panel data. The Econometrics Journal, 3(2), 148-161.

Hannan, T., \& Berger, A. (1991). The rigidity of prices: Evidence from the banking industry. American Economic Review, 81(4), 938-945.

Heinemann, F., \& Schüller, M. (2002). Integration benefits on EU retail markets: Evidence from interest rate pass-through (Discussion Paper No. 02-26). Mannheim, Germany: Zentrum für Europäische Wirtschaftsforschung.

Hofmann, B., \& Mizen, P. (2004). Interest rate pass-through and monetary transmission: Evidence from individual financial institutions' retail rates. Economica, 71, 99-123.

Hulsewig, O., Mayer, E., \& Wollmershauser, T. (2006). Bank loan supply and monetary policy transmission in Germany: An assessment based on matching impulse responses. Journal of Banking and Finance, 30, 2893-2910.

Im, K. S., Pesaran, M. H., \& Shin, Y. (2003). Testing for unit roots in heterogeneous panels. Journal of Econometrics, 115, 53-74.

Kashyap, A. K., \& Stein, J. (2000). What do a million observations on banks say about the transmission of monetary policy? American Economic Review, 86, 310-314.

Kleimeier, S., \& Sander, H. (2006). Expected versus unexpected monetary policy impulses and interest rate pass-through in Eurozone retail banking. Journal of Banking and Finance, 30, 1839-1870. 
Levin, A., Lin, C. F., \& Chu, C. (2002). Unit root tests in panel data: Asymptotic and finite sample properties. Journal of Econometrics, $108,1-24$.

Liu, M.-H., Margaritis, D., \& Tourani-Rad, A. (2008). Monetary policy transparency and pass-through of retail interest rates. Journal of Banking and Finance, 32, 501-511.

Mishkin, F. S. (1995). Symposium on the monetary transmission mechanism. Journal of Economic Perspectives, 9(4), 3-10.

Mohsin, H., \& Rivers, P. (in press). Are domestic banks' interest rate passthroughs higher than foreign banks? Empirical evidence from Pakistan. International Journal of Economics and Finance, November.

Mojon, B. (2000). Financial structure and the interest rate channel of ECB monetary policy (Working Paper No. 40). Frankfurt, Germany: European Central Bank.

Orsal, D. D. K. (2007). Comparison of panel cointegration tests (SFB 649 Discussion Paper No. 029). Berlin, Germany: HumboldtUniversität zu Berlin.

Ozdemir, B. K. (2009). Retail bank interest rate pass-through: The Turkish experience. International Research Journal of Finance and Economics, 28, 7-15.

Pedroni, P. (1999). Critical values for cointegration tests in heterogeneous panels with multiple regressors [Special issue]. Oxford Bulletin of Economics and Statistics. November, 653-670.

Pedroni, P. (2004). Panel cointegration: Asymptotic and finite sample properties of pooled time series with an application to the PPP hypothesis. Econometric Theory, 20, 597-625.

Phillips, P. C. B., \& Loretan, M. (1991). Estimating long-run equilibria. Review of Economic Studies, 58, 407-436.

Qayyum, A., Khan, S., \& Khawaja, M. I. (2005). Interest rate pass-through in Pakistan: Evidence from transfer function approach. Pakistan Development Review, 44(4), 975-1001. 
Romer, C., \& Romer, D. (1989). Does monetary policy matter? A new test in the spirit of Friedman and Schwartz. National Bureau of Economic Research Macroeconomic Annual, 4, 121-170.

Rousseas, S. (1985). A markup theory of bank loan rates. Journal of Post Keynesian Economics, 8(1), 144-153.

Sander, H., \& Kleimeier, S. (2002). Asymmetric adjustment of commercial bank interest rates in the Euro area: An empirical investigation into interest rate pass-through. Kredit und Kapital, 35(2), 161-192.

Sander, H., \& Kleimeier, S. (2004). Interest rate pass-through in an enlarged Europe: The role of banking market structure for monetary policy transmission in transitional countries (Mimeo). Maastricht, Holland: Maastricht Research School of Economics of Technology and Organization.

Sørensen, C. K., \& Werner, T. (2006). Bank interest rate pass-through in the Euro area: A cross-country comparison (Working Paper No. 580). Frankfurt, Germany: European Central Bank.

Tieman, A. (2004). Interest rate pass-through in Romania and other central European economies (Working Paper No. 04/211). Washington, DC: International Monetary Fund.

Toolsema, L. A., Sturm, J.-E., \& Haan, J. de (2002). Convergence of monetary transmission in EU: New evidence (Working Paper No. 465). Munich, Germany: CESifo.

Van Leuvensteijn, M., Sørensen, C. K., Bikker, J. A., \& Van Rixtel, A. (2008). Impact of bank competition on the interest rate pass-through in the Euro area (Working Paper No. 885). Frankfurt, Germany: European Central Bank.

Vega, E., \& Rebucci, A. (2003). Retail bank interest rate pass-through: Is Chile atypical? (Working Paper No. 03/112). Washington, DC: International Monetary Fund.

Weth, M. A. (2002). The pass-through from market interest rates to bank lending rates in Germany (Discussion Paper No. 11/02). Frankfurt, Germany: Deutsche Bundesbank. 